Such side effects rule out the use of 5FC for vulval candidiasis except where this is disabling. Such cases do, however, ocour, and the patient described above has been transformed from an anxious, depressed woman to a happy housewife, all her family sharing the benefits.

The 5-PC was provided by $\mathrm{Dr}$. J. Garrod of Roche Products Ltd. Microbiological investigations were performed by Dr. A. T. Willis and blood 5-FC

tory.

Luton and Dunstable Hospital,

Luton, Beds

Stanley A. Seligman

\section{Cot Deaths}

SIR,-In your leading article (2 March, p. 341) on cot deaths, also referred to as the sudden infant death syndrome (S.I.D.S.), it was stated that "post-mortem examination of infants with S.I.D.S. has shown an adequate cause of death, such as pneumonia, acute bronchiolitis, or gastroenteritis in $25 \%$ to $50 \%$ of cases." I feel that it would have been more appropriate to define S.I.D.S. precisely in your article and adhere to the definition throughout the course of your discussion. Thus both semantic confusion and the inflation of the incidence of S.I.D.S. by $25-50 \%$ would have been avoided.

At present a widely recognized definition of S.I.D.S. is "the sudden death of an infant or young child, unexpected by history, in which a thorough postmortem examination fails to demonstrate an adequate cause of death." Prior to 1970 to most investigators S.I.D.S. was the death of an infant or child who was thought to be in good health or whose terminal illness proved to be so mild that the possibility of a fatal outcome was unexpected. However, unless we adhere to a generally acceptable definition, studies on S.I.D.S. either to evaluate its true incidence or to elucidate the cause and/or mechanism of death are bound to have a limited significanoe.-I am, etc.,

\section{Department of Pathology,} Faculty of Medicine,

1 Sudden Infant Death Syndrome: Proceedings of the Second International Conference on Causes
of Sudden Deah in Infants, ed. A B Bergman,
J. B. Beckwith, and C. G. Ray. Seattle, Univerof Suden Deah in Infants, ed. Beckwith, and C. G. Ray.
sity of Washington Press, 1970 .

\section{Meningioma Mimicking Features of a} Phaeochromocytoma

SIR,-Drs. R. Gabriel and B. D. Harrison (11 May, p. 312) repont a case of supratentorial meningioma mimicking the clinical and biochemical features of phaeochromocytoma in which the raised vanilmandelic acid (VMA) excretion returned to normal after nemoval of the tumour. The explanation offered, that raised intracranial pressure had produced these features through stimulation of the sympathetiooadrenal pathway, is not the onily possible one and not perhaps the most likely.

Since the time of Cushing ${ }^{1}$ vasomotor changes have been accepted as part of the olinical picture of raised intracranial pressure; such changes occur usually only with a rapid pressure rise ${ }^{2}$ and then incomstantly and mainly in children with lesions that directly compromise the posterior fossa. ${ }^{3-5}$ In the case described no mention is made of papilloedema and the lumbar cerebrospinal fluid pressure was only $270 \mathrm{~mm}$.

The association of phaeochromocytomas and meningiomas with von Recklinghausen's disease is well acoepted, the link probably lying in the common neural-cnest ancestors of these tumours. Other neural tumours have been reported as seoreting VMA. ${ }^{6}$ Is it not probable that the meningioma may on occasion have this capacity? After all, other intracranial tumours, the haemangioblastomas, secrete hormones and the latter is found in association with phaeochromocytomas. It would have been of interest to know the cytochemical characteristics of this patient's tumour.-I am, etc.,

Department of Medicine,

Birmingham

1 Cushing, H., American foumal of Medical Sciences, 1902, 124, 376.

Pickering, G. W., High Blood Pressure, p. 520, 2nd edn. New York, Grune and Stratton, 1968. 1938,36, ,

Johnston, I. H., Johnston, J. A., and Jennett, B., Lancet, 1970, $2,433$.

5 Plum, F.. and Posner, J. B., Diagnosis of Stupor and Coma, 2nd edn., p. 32. Philadelphia, David, 1972 .

6 Kogut, M. D., and Kaplan, S. A.. Fournal of Pediatrics, 1962, 60, 694 .

\section{The Heart during Sleep}

SIR,-With refenence to your leading anticle (13 April, p. 70) in the beginning of openheart surgery in the 1950 s it was recognized from first principles and practical experience that pain, fear, and exhaustion predisposed to death from arrhythmia, and the protective value of providing adequate sleep was quickly appreciated.

In the early 1960s coronary care units appeared and some of us introduced, and continued to find useful in threatened and acute myocardial infarction, ${ }^{1-4}$ the sleep regimens that we had developed in the surgical wands.-I am, etc.

Charing Cross Hospital (Fulham),

P. G. NIXON London $W .6$

1 Nixon, P. G. F.. et al., Lancet, 1968, 1, 726 Nixon, P. G. F., in Recent Advances in Medicine, ed. D. N. Baron, N. Compsto

3 Nixon, P. G. F., in Seventh Symposium on Advanced Medicine, ed. I. A. D. Bouchie 4 Nixon, P. G. F., Practitioner, 1973, 211, 5.

\section{Blind Babies}

SIR,-I was pleased to read your leading article (8 June, p. 518) on xerophthalmia, the blinding diseaise due basically to a lack of vitamin $A$ in the food. It is a scourge in many countries yet little is taught abour it in medical schools in the West. This is partiicularly unfortumate at present as preventive schemes are stanting in many parts of the world and accurate diagnosis is essential. The Governments of India, Indonesia, and Bangladesh are distributing, each six months, a large dose of vitamin A (300,000 IU) in oil by mouth to children under 5 years old in the hope that this will maintain a satisfactory level of vitamin $A$ in the liver and blood. The results of these measures are not yet available, but one hopes that the impact will be great and that the stream of malnounished childiren with xerophthaimia coming daily to paediatric and ophthalmic outpatient clinics will be reduced.

However, such children, who ane the most at risk of going blind, can be effectively treated at a relatively smail cost. At Madurai in Southern India, Dr. Venkataswany direots a nutrition centre for children suffering from malnutrition and xerophthalmia where the child and parent (usually mother) are given food which provides vitamin A and which is both local and cheap. In practice this means provision of about an ounce (28 g) a day of well-boiled and mashed carrots or dark green leafy vegetables such as spinach, amaranth, drumstick leaves, or turnip tops. The rest of the food is designed to supply a good level of protein and callonies. The parents do the marketing and cooking and are encouraged to contimue the food when they go home. The results have been sufficiently encouraging for the work to be extended into surrounding villages.

The Xerophthalmia Club exists to help preventive measures. A current activity is an antempt to encourage governments and charitable bodies which send dried skim milk to disaster areas to ensure that all such milk is fortified with vitamin $A$. If pnotein food is given to a malnourished child already defiaient in vitamin $A$ the last remnants of vitamin $A$ in the body are used up and xerophthalmia may be precipitated. Such disasters still occur. ${ }^{1}$ Unicef and the Governments of the United States and the Netherlands have alneady agreed that all dried skim milk exported shall oontain vitamin A. We hope this will become univensal.

The Xerophthalmia Club is financed entirely by the Royal Commonwealth Society for the Blind. There is no membership subscription for those seriously interested in the prevention of xerophthalmia.-I am, etc.,

ANTONNetTe PIRIE Hon. Secretary, Xerophthalmia Club Girton College, Cambridge

1 Oomen, H. A. P. C., Xerophthalmia Club

\section{Forensic Neuropsychiatry}

SIR,-I disagnee with some of Dr. M. F. Cleary's comments in his Personal View (1 June, p. 498) about the psychiatrist in count. Of course psychiatry is a woolly subject, but it need not be quite as woolly as some psychiatric witnesses make it seem.

As Cuthbent ${ }^{1}$ has pointed out, senious crime may be a manifestation of brain disease, especially when the offence is not readily "understandable." In thiis situation it is not enough to onder a neurological examination and E.E.G., both of which may give entirely normal results in the presence of significant disease. ${ }^{2} 3$ I believe it is essential, if justice is to be done, to offer a thorough neuropsychiatric investigation. In practice this will usually require a brain scan, air encephalography, psychometry, and in some cases a sphenoidal E.E.G. as well. In this way, significant brain disease is unlikely to be overlooked. Indeed, there is no other way of assessing the cerebral atrophy which frequently acoompanies alooholism, ${ }^{2}$ and the relationship between crime and alooholism is well known. Some tentative diagnoses of temporal lobe epilepsy are clinched when the air enoephalogram shows marked temporal atrophy. ${ }^{3}$ Retrospective diagnosis, 